\title{
Enantio- and Diastereoselective, Stereospecific Mannich-type Reactions in Water
}

\author{
Tomoaki Hamada, Kei Manabe, and Shū Kobayashi* \\ Graduate School of Pharmaceutical Sciences, The University of Tokyo, \\ Hongo, Bunkyo-ku, Tokyo 113-0033, Japan.
}

\section{Supporting Information}

\section{Table of Contents}

Pages

Experimental

Typical Experimental Procedures for the Mannich-type Reactions

Crystallization of $\left[\mathrm{ZnCl}_{2}-1 \mathrm{~b} \cdot \mathrm{CH}_{2} \mathrm{Cl}_{2}\right]$ complexes

Determination of the relative configuration of Mannich adduct 5

Determination of the absolute and relative configurations of

Mannich adduct 9

References

Ortep drawing of $\left[\mathrm{ZnCl}_{2}-\mathbf{1} \mathbf{b} \cdot \mathrm{CH}_{2} \mathrm{Cl}_{2}\right]$

Ortep drawing of $\mathbf{8}$

\section{Experimental}

General: Melting points were uncorrected. $\mathrm{CDCl}_{3}$ was used as a solvent for ${ }^{1} \mathrm{H}$ and ${ }^{13} \mathrm{C}$ NMR spectra unless otherwise noted. Tetramethylsilane (TMS) served as an internal standard $(\delta=0)$ for ${ }^{1} \mathrm{H}$ NMR and $\mathrm{CDCl}_{3}$ as an internal standard $(\delta=77.0)$ for ${ }^{13} \mathrm{C}$ NMR. In the case using dimethylsulfoxide- $d_{6}$ (DMSO- $d_{6}$ ) as a solvent, the methyl peak of DMSO was served as an internal standard (2.49 ppm in ${ }^{1} \mathrm{H}$ NMR, $39.5 \mathrm{ppm}$ in ${ }^{13} \mathrm{C}$ NMR). Preparative thin-layer chromatography was carried out using Wakogel B5F. $\mathrm{ZnF}_{2}$ was purchased from Soekawa Rikagaku Co., LTD. $(1 R, 2 R)-(+)-1,2-$ Diphenyl-1,2-ethanediamine was purchased from Kanto Kagaku CO., LTD. 
Acetophenone-derived Silyl Enol Ether in Water: To a mixture of 1c $(0.0430$ mmol) and $\mathrm{ZnF}_{2}(0.430 \mathrm{mmol})$ in $\mathrm{H}_{2} \mathrm{O}(2.33 \mathrm{~mL})$ was added a $0.0936 \mathrm{M}$ solution of $\mathrm{NaOTf}(0.00430 \mathrm{mmol})$ in $\mathrm{H}_{2} \mathrm{O}, 2(0.430 \mathrm{mmol})$, and acetophenone-derived silyl enol ether $(1.29 \mathrm{mmol})$, and the mixture was stirred vigorously $(\sim 1400 \mathrm{rpm})$ at $0{ }^{\circ} \mathrm{C}$. After $20 \mathrm{~h}$, the reaction was quenched with saturated aqueous $\mathrm{NaHCO}_{3}$. The resultant mixture was extracted with dichloromethane (3 times), and the combined organic layers were dried over anhydrous $\mathrm{Na}_{2} \mathrm{SO}_{4}$. The solvent was evaporated, and the residue was purified by preparative TLC (silica gel, chloroform/MeOH (39/1), and then hexane/ethyl acetate (1/1)) to give the Mannich adduct (92\% yield). The enantiomeric excess of the product was determined by HPLC analysis ( $96 \%$ ee). The spectral data of the product were previously reported. ${ }^{1}$

\section{A Typical Experimental Procedure for the Mannich-type Reactions with} Propiophenone-derived Silyl Enol Ether in Water: To a mixture of $\mathrm{ZnF}_{2}(0.400$ mmol) and $\mathbf{1 b}(0.0400 \mathrm{mmol})$ in $\mathrm{H}_{2} \mathrm{O}(1.95 \mathrm{~mL})$ was added a $0.0716 \mathrm{M}$ solution of CTAB (0.0200 mmol) in $\mathrm{H}_{2} \mathrm{O}, 2(0.400 \mathrm{mmol})$, and propiophenone-derived silyl enol ether $(1.20 \mathrm{mmol})$, and the mixture was stirred vigorously $(\sim 1400 \mathrm{rpm})$ at $0{ }^{\circ} \mathrm{C}$. After $20 \mathrm{~h}$, the reaction was quenched with saturated aqueous $\mathrm{NaHCO}_{3}$. The resultant mixture was extracted with dichloromethane (3 times), and the combined organic layers were dried over anhydrous $\mathrm{Na}_{2} \mathrm{SO}_{4}$. The solvent was evaporated, and the residue was purified by preparative TLC (silica gel, hexane/ethyl acetate (2/1), twice) to give the Mannich adduct $(94 \%$ yield, syn/anti $=94 / 6)$. The enantiomeric excess of the product was determined by HPLC analysis (97\% ee). The spectral data of the product were previously reported. ${ }^{1}$<smiles>CCOC(=O)[C@H](NN[18O])C(=O)c1ccccc1</smiles>

Ethyl 2-(N'-benzoylhydrazino)-3-ethyl-4-oxo-4-phenylbutyrate: Diastereomeric ratio of the product was determined from the ratio of integration of each peak on ${ }^{1} \mathrm{H}$ NMR analysis.

Syn. $\left(\right.$ syn/anti $=99 / 1,>99.5 \%$ ee $($ syn) $)$ : $\mathrm{mp}: 88-91{ }^{\circ} \mathrm{C} ;[\alpha]_{\mathrm{D}}^{27}+13.2\left(\right.$ c 2.72, $\left.\mathrm{CHCl}_{3}\right)$; IR (KBr) 3269, 1732, 1682, 1628, 1551, 1194, $706 \mathrm{~cm}^{-1} ;{ }^{1} \mathrm{H}$ NMR $\left(\mathrm{CDCl}_{3}\right): \delta 0.97(\mathrm{t}$, $3 \mathrm{H}, J=7.3 \mathrm{~Hz}), 1.20(\mathrm{t}, 3 \mathrm{H}, J=7.1 \mathrm{~Hz}), 1.75-1.90(\mathrm{~m}, 2 \mathrm{H}), 3.93(\mathrm{ddd}, 1 \mathrm{H}, J=6.9$, 
6.9, 7.6 Hz), 4.04 (d, 1H, $J=7.6 \mathrm{~Hz}), 4.08-4.23$ (m, 2H), 5.09 (brs, 1H), 7.35-7.51 $(\mathrm{m}, 5 \mathrm{H}), 7.53-7.59(\mathrm{~m}, 1 \mathrm{H}), 7.71(\mathrm{~d}, 2 \mathrm{H}, J=7.3 \mathrm{~Hz}), 7.96(\mathrm{~d}, 2 \mathrm{H}, J=7.6 \mathrm{~Hz}), 8.20(\mathrm{~s}$, 1H) $\mathrm{ppm} ;{ }^{13} \mathrm{C} \mathrm{NMR}\left(\mathrm{CDCl}_{3}\right): \delta 11.6,14.0,22.7,48.9,61.4,64.8,126.9,128.3,128.5$, 128.7, 131.7, 132.6, 133.3, 137.2, 166.6, 172.5, 202.1 ppm; HRMS (FAB) calcd for $\mathrm{C}_{21} \mathrm{H}_{25} \mathrm{~N}_{2} \mathrm{O}_{4}\left([\mathrm{M}+\mathrm{H}]^{+}\right): 369.1814$, found: 369.1834; Anti: ${ }^{1} \mathrm{H}$ NMR $\left(\mathrm{CDCl}_{3}\right): \delta 0.93(\mathrm{t}$, $3 \mathrm{H}, J=7.3 \mathrm{~Hz}), 1.25(\mathrm{t}, 3 \mathrm{H}, J=7.1 \mathrm{~Hz}), 1.78-1.92(\mathrm{~m}, 1 \mathrm{H}), 2.01-2.16(\mathrm{~m}, 1 \mathrm{H}), 3.99$ (ddd, 1H, $J=5.0,5.1,7.8 \mathrm{~Hz}), 4.07(\mathrm{~d}, 1 \mathrm{H}, J=5.0 \mathrm{~Hz}), 4.17-4.28(\mathrm{~m}, 2 \mathrm{H}), 4.96$ (brs, $1 \mathrm{H})$, 7.35-7.57 (m, 6H), 7.62-7.68 (m, 2H), 7.93-8.01 (m, 3H) ppm; ${ }^{13} \mathrm{C}$ NMR $\left(\mathrm{CDCl}_{3}\right): \delta 11.9,14.0,21.7,48.7,61.5,63.5,126.8,128.4,128.5,128.7,131.8,132.4$, 133.3, 136.5, 166.8, 171.8, 201.7 ppm; HPLC (Daicel Chiralpak AD-H, hexane/i$\mathrm{PrOH}=4 / 1$, flow rate $=0.70 \mathrm{~mL} / \mathrm{min}$ ) $S y n: t_{\mathrm{R}}=18.3 \mathrm{~min}$ (major), $t_{\mathrm{R}}=29.4 \mathrm{~min}$ (minor). Anti: $t_{\mathrm{R}}=20.2 \mathrm{~min}, t_{\mathrm{R}}=25.2 \mathrm{~min}$.

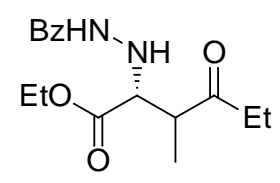

Ethyl 2-( $N$ '-benzoylhydrazino)-3-methyl-4-oxohexanoate: Diastereomeric ratio of the product was determined from the ratio of integration of the 2-methine proton on ${ }^{1} \mathrm{H}$ NMR analysis.

Syn. $\left(\right.$ syn/anti $=98.5 / 1.5,>99.5 \%$ ee $($ syn) $): \mathrm{mp}: 117-119{ }^{\circ} \mathrm{C} ;[\alpha]^{25}+8.3(c 0.25$, $\mathrm{CHCl}_{3}$ ); IR (KBr) 3251, 1730, 1711, 1626, 1556, 1452, 1205, $694 \mathrm{~cm}^{-1}$; ${ }^{1} \mathrm{H}$ NMR $\left(\mathrm{CDCl}_{3}\right): \delta 1.06(\mathrm{t}, 3 \mathrm{H}, J=7.2 \mathrm{~Hz}), 1.23(\mathrm{~d}, 3 \mathrm{H}, J=7.2 \mathrm{~Hz}), 1.26(\mathrm{t}, 3 \mathrm{H}, J=7.2 \mathrm{~Hz})$, 2.43-2.66 (m, 2H), $3.08(\mathrm{dq}, 1 \mathrm{H}, J=7.2,7.2 \mathrm{~Hz}), 3.87(\mathrm{~d}, 1 \mathrm{H}, J=7.2 \mathrm{~Hz}), 4.12-4.30$ (m, 2H), 4.84 (brs, 1H), 7.37-7.56 (m, 3H), 7.70-7.79 (m, 2H), $8.08(\mathrm{~s}, 1 \mathrm{H}) \mathrm{ppm} ;{ }^{13} \mathrm{C}$ $\operatorname{NMR}\left(\mathrm{CDCl}_{3}\right): \delta 7.6,13.5,14.1,34.7,47.1,61.3,65.5,126.9,128.6,131.8,132.6$, 166.7, 172.0, $212.2 \mathrm{ppm}$; HRMS (ESI-TOF) calcd for $\mathrm{C}_{16} \mathrm{H}_{22} \mathrm{~N}_{2} \mathrm{O}_{4} \mathrm{Na}\left([\mathrm{M}+\mathrm{Na}]^{+}\right)$: 329.1477, found: 329.1460; Anti: ${ }^{1} \mathrm{H} \mathrm{NMR}\left(\mathrm{CDCl}_{3}\right): \delta 1.04$ (t, $\left.3 \mathrm{H}, J=7.2 \mathrm{~Hz}\right), 1.25$ $(\mathrm{d}, 3 \mathrm{H}, J=7.2 \mathrm{~Hz}), 1.26(\mathrm{t}, 3 \mathrm{H}, J=7.2 \mathrm{~Hz}), 2.48-2.70(\mathrm{~m}, 2 \mathrm{H}), 3.11(\mathrm{dq}, 1 \mathrm{H}, J=4.9$, $7.2 \mathrm{~Hz}), 3.98(\mathrm{dd}, 1 \mathrm{H}, J=4.5,4.9 \mathrm{~Hz}), 4.10-4.29(\mathrm{~m}, 2 \mathrm{H}), 5.35(\mathrm{dd}, 1 \mathrm{H}, J=4.5,5.5$ $\mathrm{Hz}), 7.36-7.54(\mathrm{~m}, 3 \mathrm{H}), 7.70-7.78(\mathrm{~m}, 2 \mathrm{H}), 8.18(\mathrm{brd}, 1 \mathrm{H}, J=5.5 \mathrm{~Hz}) \mathrm{ppm} ;{ }^{13} \mathrm{C} \mathrm{NMR}$ $\left(\mathrm{CDCl}_{3}\right): \delta 7.5,12.4,14.0,34.3,46.9,61.3,64.0,126.8,128.5,131.7,132.4,166.9$, 171.7, 212.3 ppm; HPLC (Daicel Chiralpak AD-H, hexane $/ i-\mathrm{PrOH}=9 / 1$, flow rate $=$ $0.80 \mathrm{~mL} / \mathrm{min}$ ) Syn: $t_{\mathrm{R}}=23.9 \mathrm{~min}$ (minor), $t_{\mathrm{R}}=33.7 \mathrm{~min}$ (major). Anti: $t_{\mathrm{R}}=26.7 \mathrm{~min}$ (minor), $t_{\mathrm{R}}=44.3 \min$ (major). 
<smiles>CCCCC(=O)C(C)C(NN[R8](=O)c1ccccc1)C(=O)OCC</smiles>

E th y $1 \quad 2$ - (N'-benzoylhydrazino)-4-tert-butylthio-3-methyl-4-oxobutanoate:

Diastereomeric ratio of the product was determined from the ratio of integration of the 2-methine proton on ${ }^{1} \mathrm{H}$ NMR analysis.

Syn: ${ }^{1} \mathrm{H}$ NMR $\left(\mathrm{CDCl}_{3}\right): \delta 1.28(\mathrm{t}, 3 \mathrm{H}, J=7.2 \mathrm{~Hz}), 1.31(\mathrm{~d}, 3 \mathrm{H}, J=7.1 \mathrm{~Hz}), 1.44(\mathrm{~s}$, 9H), $3.12(\mathrm{dq}, 1 \mathrm{H}, J=4.3,7.1 \mathrm{~Hz}), 4.00(\mathrm{dd}, 1 \mathrm{H}, J=3.7,4.3 \mathrm{~Hz}), 4.15-4.29$ (m, 2H), $5.50(\mathrm{dd}, 1 \mathrm{H}, J=3.7,6.3 \mathrm{~Hz}), 7.38-7.44(\mathrm{~m}, 2 \mathrm{H}), 7.46-7.52(\mathrm{~m}, 1 \mathrm{H}), 7.71-7.77(\mathrm{~m}$, $2 \mathrm{H}), 8.08$ (brd, $1 \mathrm{H}, J=6.3 \mathrm{~Hz}) \mathrm{ppm} ;{ }^{13} \mathrm{C} \mathrm{NMR}\left(\mathrm{CDCl}_{3}\right): \delta 13.2,14.0,29.6,48.3,49.5$, 61.4, 64.5, 126.9, 128.5, 131.7, 132.5, 166.7, 171.1, 201.8 ppm; Anti: IR (neat) $($ syn/anti $=8 / 92): 3292,2966,1738,1680,1456,1211,964,696 \mathrm{~cm}^{-1} ;{ }^{1} \mathrm{H} \mathrm{NMR}$ $\left(\mathrm{CDCl}_{3}\right): \delta 1.27(\mathrm{t}, 3 \mathrm{H}, J=7.1 \mathrm{~Hz}), 1.29(\mathrm{~d}, 3 \mathrm{H}, J=7.1 \mathrm{~Hz}), 1.47(\mathrm{~s}, 9 \mathrm{H}), 3.10(\mathrm{dq}$, $1 \mathrm{H}, J=6.8,7.1 \mathrm{~Hz}), 3.85(\mathrm{dd}, 1 \mathrm{H}, J=6.2,6.8 \mathrm{~Hz}), 4.09-4.35(\mathrm{~m}, 2 \mathrm{H}), 5.32(\mathrm{dd}, 1 \mathrm{H}, J$ $=5.4,6.2 \mathrm{~Hz}), 7.39-7.56(\mathrm{~m}, 3 \mathrm{H}), 7.70-7.79(\mathrm{~m}, 2 \mathrm{H}), 7.94(\mathrm{brd}, 1 \mathrm{H}, J=5.4 \mathrm{~Hz}) \mathrm{ppm}$; ${ }^{13} \mathrm{C} \mathrm{NMR}\left(\mathrm{CDCl}_{3}\right): \delta 14.1,14.5,29.7,48.4,49.4,61.4,65.9,126.9,128.6,131.8$, 132.6, 166.9, 171.4, 201.4 ppm; HRMS (FAB) calcd for $\mathrm{C}_{18} \mathrm{H}_{27} \mathrm{~N}_{2} \mathrm{O}_{4} \mathrm{~S}\left([\mathrm{M}+\mathrm{H}]^{+}\right)$: 367.1692, found: 367.1671; HPLC (Daicel Chiralpak AD-H (double), hexane/i-PrOH $=4 / 1$, flow rate $=0.50 \mathrm{~mL} / \mathrm{min}$ ) $S y n: t_{\mathrm{R}}=34.8 \mathrm{~min}$ (minor), $t_{\mathrm{R}}=41.4 \mathrm{~min}$ (major). Anti: $t_{\mathrm{R}}=28.8 \min$ (minor), $t_{\mathrm{R}}=33.1 \mathrm{~min}$ (major).

\section{Crystallization of $\left[\mathrm{ZnCl}_{2}-1 \mathrm{~b} \cdot \mathrm{CH}_{2} \mathrm{Cl}_{2}\right]$ complexes}

Crystallization of $\left[\mathrm{ZnCl}_{2}-\mathbf{1} \mathbf{b} \cdot \mathrm{CH}_{2} \mathrm{Cl}_{2}\right]$ was carried out as follows: To a suspension of $\mathrm{ZnCl}_{2}(0.039 \mathrm{mmol})$ in $\mathrm{CH}_{2} \mathrm{Cl}_{2}(0.81 \mathrm{~mL})$ was added a solution of $\mathbf{1 b}$ $(0.032 \mathrm{mmol})$ in $\mathrm{CH}_{2} \mathrm{Cl}_{2}(0.81 \mathrm{~mL})$, and the mixture was stirred for $16 \mathrm{~h}$ at $\mathrm{rt}$. The resulting clear solution was filtered, and the filtrate was allowed to stand at $5{ }^{\circ} \mathrm{C}$ under hexane vapor to give the colorless crystals.

\section{Determination of the relative configuration of Mannich adduct 5}

The relative configuration of $\mathbf{5}$ obtained in Table 3, entry 1 was determined to be syn by the X-ray analysis, after conversion to lactone 8 (eq. 1). Mannich adduct 5 was used after increasing both the diastereo- and enantiomerically excess by one recrystallization $($ syn/anti $=98.5 / 1.5,>99.5 \%$ ee $($ syn $)$ ). 


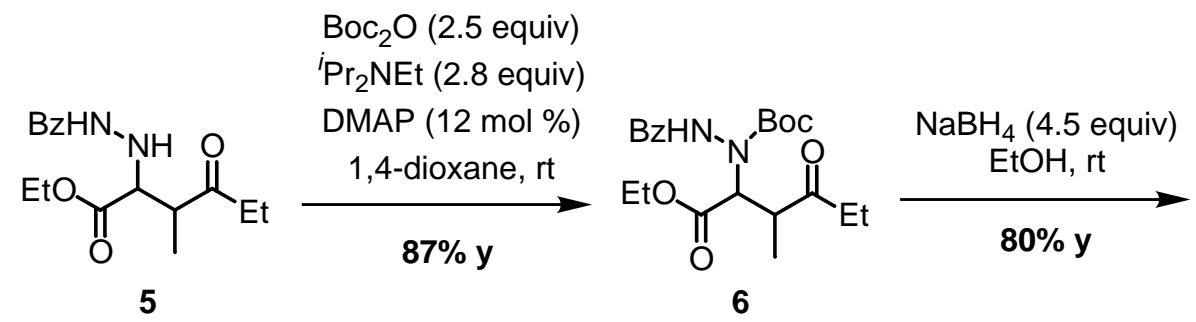

syn/anti $=98.5 / 1.5$

$>99.5 \%$ ee (syn)<smiles>CCC1OC(=O)C(N(NC(=O)OCc2ccccc2)C(=O)OCc2ccccc2)C1C</smiles>

7

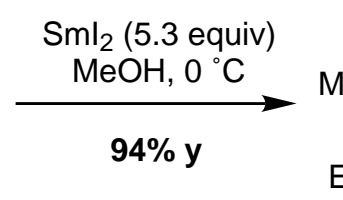

$\mathrm{Et}$

(dr: 77/23)

6: To a solution of $5(0.103 \mathrm{mmol})$ in 1,4-dioxane $(0.18 \mathrm{~mL})$ were added a solution of $i-\operatorname{Pr}_{2} \mathrm{NEt}(0.144 \mathrm{mmol})$ and di-tert-butyl dicarbonate $(0.129 \mathrm{mmol})$ in $1,4-$ dioxane $(1.50 \mathrm{~mL})$ and 4 -(dimethylamino)pyridine $(0.012 \mathrm{mmol})$ at rt. After stirring for $13 \mathrm{~h}$, a solution of $i$ - $\mathrm{Pr}_{2} \mathrm{NEt}(0.149 \mathrm{mmol})$ and di-tert-butyl dicarbonate $(0.132$ mmol) in 1,4-dioxane $(1.20 \mathrm{~mL})$ was added to the mixture. After stirring for $2 \mathrm{~h}$, the reaction was quenched with water. The resultant mixture was extracted with $\mathrm{CH}_{2} \mathrm{Cl}_{2}$ (3 times), and the combined organic layers were dried over anhydrous $\mathrm{Na}_{2} \mathrm{SO}_{4}$. The solvents were evaporated, and the residue was purified by preparative TLC (silica gel, hexane/ethyl acetate (3/1)) to give 6 ( $87 \%$ yield). $[\alpha]^{24}-60.0$ (c 1.49, $\mathrm{CHCl}_{3}$ ); IR (neat): 3325, 2979, 1716, 1477, 1369, 1277, 1153, $756 \mathrm{~cm}^{-1}$; ${ }^{1} \mathrm{H}$ NMR (DMSO- $\left.d_{6}, 110{ }^{\circ} \mathrm{C}\right): \delta 0.92(\mathrm{t}, 3 \mathrm{H}, J=7.2 \mathrm{~Hz}), 1.10(\mathrm{~d}, 3 \mathrm{H}, J=$ $7.3 \mathrm{~Hz}), 1.21(\mathrm{t}, 3 \mathrm{H}, J=7.1 \mathrm{~Hz}), 1.39(\mathrm{~s}, 9 \mathrm{H}), 2.53(\mathrm{q}, 2 \mathrm{H}, J=7.2 \mathrm{~Hz}), 3.12(\mathrm{dq}, 1 \mathrm{H}$, $J=7.2,7.5 \mathrm{~Hz}), 4.13(\mathrm{q}, 2 \mathrm{H}, J=7.1 \mathrm{~Hz}), 5.02(\mathrm{~d}, 1 \mathrm{H}, J=7.5 \mathrm{~Hz}), 7.43-7.50(\mathrm{~m}, 2 \mathrm{H})$, 7.51-7.59 (m, 1H), 7.76-7.82 (m, 2H), $9.76(\mathrm{~s}, 1 \mathrm{H}) \mathrm{ppm} ;{ }^{13} \mathrm{C}$ NMR (DMSO- $d_{6}, 110$ $\left.{ }^{\circ} \mathrm{C}\right): \delta 6.8,12.7,13.2,27.3,32.5,44.5,60.0,61.1,80.4,126.9,127.7,131.0,132.4$, 153.3, 166.4, 168.1, 209.0 ppm; HRMS (FAB) calcd for $\mathrm{C}_{21} \mathrm{H}_{31} \mathrm{~N}_{2} \mathrm{O}_{6}\left([\mathrm{M}+\mathrm{H}]^{+}\right)$: 407.2182, found: 407.2193.

7: $\mathrm{NaBH}_{4}(0.410 \mathrm{mmol})$ was added to a solution of $\mathbf{6}(0.0900 \mathrm{mmol})$ in $\mathrm{EtOH}$ (3.4 $\mathrm{mL}$ ) at rt. After stirring for $40 \mathrm{~min}$ at $\mathrm{rt}$, the reaction was quenched with water $(10 \mathrm{~mL})$. The resultant mixture was extracted with ethyl acetate $(30 \mathrm{~mL}, 3$ times), and the combined organic layers were dried over anhydrous $\mathrm{Na}_{2} \mathrm{SO}_{4}$. The solvents were 
evaporated, and the residue was purified by preparative TLC (silica gel, hexane/ethyl acetate $(3 / 1))$ to give 7 (80\% yield, 3,4-cis/3,4-trans $=78 / 22)$. Diastereomeric ratio of the product was determined from the ratio of integration of the methyl proton at $\mathrm{C} 3$ on ${ }^{1} \mathrm{H}$ NMR analysis.

IR (KBr): 3307, 2978, 1780, 1712, 1365, 1302, 1147, $960 \mathrm{~cm}^{-1} ;{ }^{1} \mathrm{H}$ NMR (DMSO- $d_{6}$, $\left.70{ }^{\circ} \mathrm{C}\right) 3,4-C i s$ isomer: $\delta 0.92(\mathrm{t}, 3 \mathrm{H}, J=7.3 \mathrm{~Hz}), 1.13(\mathrm{~d}, 3 \mathrm{H}, J=7.0 \mathrm{~Hz}), 1.37(\mathrm{~s}$, 9H), 1.45-1.57 (m, 1H), 1.57-1.66 (m, 1H), 2.70-2.84 (m, 1H), 4.44 (ddd, 1H, $J=3.7$, 8.2, 10.1 Hz), 4.48-4.64 (m, 1H), 7.43-7.49 (m, 2H), 7.52-7.58 (m, 1H), 7.76-7.86 (m, $2 \mathrm{H}), 10.38$ (brs, 1H) ppm; Detectable peaks of 3,4-trans isomer: $\delta 1.18(\mathrm{~d}, 3 \mathrm{H}, J=6.4$ $\mathrm{Hz}), 1.69-1.79(\mathrm{~m}, 1 \mathrm{H}), 3.96-4.06(\mathrm{~m}, 1 \mathrm{H}) \mathrm{ppm} ;{ }^{13} \mathrm{C}$ NMR (DMSO- $d_{6}, 70{ }^{\circ} \mathrm{C}$ ) Detectable peaks of 3,4-cis isomer: $\delta$ 10.1, 12.3, 22.9, 27.7, 82.1, 127.5, 128.3, 131.8, 132.3, 172.3 ppm; HRMS (FAB) calcd for $\mathrm{C}_{19} \mathrm{H}_{27} \mathrm{~N}_{2} \mathrm{O}_{5}\left([\mathrm{M}+\mathrm{H}]^{+}\right): 363.1920$, found: 363.1909 .

8: A $0.1 \mathrm{M}$ solution of $\mathrm{SmI}_{2}$ in THF $(3.8 \mathrm{~mL}, 0.38 \mathrm{mmol})$ was added to a degassed solution of $7(0.0720 \mathrm{mmol})$ in $\mathrm{MeOH}(0.77 \mathrm{~mL})$ at $0{ }^{\circ} \mathrm{C}$. After stirring for $30 \mathrm{~min}$, the reaction was quenched with water. The resultant mixture was extracted with ethyl acetate (3 times), and the combined organic layers were dried over anhydrous $\mathrm{Na}_{2} \mathrm{SO}_{4}$. The solvents were evaporated, and the residue was purified by column chromatography (silica gel, hexane/ethyl acetate (3/1)) to give 8 (94\% yield, 3,4-cis/3,4-trans $=77 / 23$ ). Diastereomeric ratio of the product was determined from the ratio of integration of the 4-methine proton on ${ }^{1} \mathrm{H}$ NMR analysis.

${ }^{1} \mathrm{H}$ NMR $\left(\mathrm{CDCl}_{3}, 45{ }^{\circ} \mathrm{C}\right) 3,4-\mathrm{Cis}$ isomer: $\delta 1.05(\mathrm{t}, 3 \mathrm{H}, J=7.4 \mathrm{~Hz}), 1.17(\mathrm{~d}, 3 \mathrm{H}, J=$ $7.0 \mathrm{~Hz}), 1.46$ (s, 9H), 1.41-1.64 (m, 1H), 1.68 (ddq, $1 \mathrm{H}, J=3.4,7.4,14.7 \mathrm{~Hz}), 2.48$ $2.58(\mathrm{~m}, 1 \mathrm{H}), 4.05-4.22(\mathrm{~m}, 1 \mathrm{H}), 4.40(\mathrm{ddd}, 1 \mathrm{H}, J=3.4,7.7,10.7 \mathrm{~Hz}), 4.83$ (brs, $1 \mathrm{H})$ ppm; Detectable peaks of 3,4-trans isomer: $\delta 1.21(\mathrm{~d}, 3 \mathrm{H}, J=6.4 \mathrm{~Hz}), 1.82(\mathrm{ddq}, 1 \mathrm{H}$, $J=3.5,7.4,14.8 \mathrm{~Hz}$ ), 2.00-2.12 (m, 1H), 3.89-3.95 (m, 1H), 4.89 (brs, 1H) ppm.

The almost pure 3,4-cis-8 was obtained from one recrystallization (EtOHhexane) to yield $6.9 \mathrm{mg}$ (39\% yield) of colorless needles suitable for X-ray analysis. mp: $121-123{ }^{\circ} \mathrm{C} ;[\alpha]^{26}{ }_{D}-84.7$ (c 0.32, $\mathrm{CHCl}_{3}$ ); IR (KBr) 3373, 2976, 1784, 1695, 1529, 1373, 1342, 1294, $1167 \mathrm{~cm}^{-1} ;{ }^{1} \mathrm{H}$ NMR $\left(\mathrm{CDCl}_{3}\right): \delta 1.06(\mathrm{t}, 3 \mathrm{H}, J=7.3 \mathrm{~Hz}), 1.17$ $(\mathrm{d}, 3 \mathrm{H}, J=6.8 \mathrm{~Hz}), 1.46(\mathrm{~s}, 9 \mathrm{H}), 1.42-1.58(\mathrm{~m}, 1 \mathrm{H}), 1.68(\mathrm{ddq}, 1 \mathrm{H}, J=3.3,7.3,14.6$ $\mathrm{Hz}), 2.46-2.60(\mathrm{~m}, 1 \mathrm{H}), 4.10-4.25(\mathrm{~m}, 1 \mathrm{H}), 4.41$ (ddd, 1H, J = 3.3, 7.8, $10.9 \mathrm{~Hz}), 4.82$ (brs, $1 \mathrm{H}) \mathrm{ppm} ;{ }^{13} \mathrm{C} \mathrm{NMR}\left(\mathrm{CDCl}_{3}\right): \delta 10.4,12.5,23.3,28.2,40.8,55.1,80.5,82.7$, 
155.7, 174.9 ppm; HRMS (ESI-TOF) calcd for $\mathrm{C}_{12} \mathrm{H}_{21} \mathrm{NO}_{4} \mathrm{Na}\left([\mathrm{M}+\mathrm{Na}]^{+}\right)$: 266.1368, found: 266.1354.

\section{Determination of the absolute and relative configurations of Mannich adduct 9}

The relative configuration of 9 obtained in the reaction with $\mathbf{4 Z}$ was determined to be syn, comparing ${ }^{1} \mathrm{H}$ NMR spectrum of $\mathbf{1 0}$ with the reported one ${ }^{2}$ (eq. 2).

On the other hand, the absolute configurations of 9 obtained in the reactions with both $4 \mathrm{E}$ and $\mathbf{4 Z}$ were determined to be $(2 R)$-form, comparing the retention time of HPLC charts of $\mathbf{1 2}$ with those of $(2 R, 3 S)-\mathbf{1 2}$ and $(2 R, 3 R)-\mathbf{1 2}$ obtained via Rapoporttype aspartate alkylation ${ }^{3}$ of $\mathbf{1 3}^{4}$ (eq. 2,3 ).

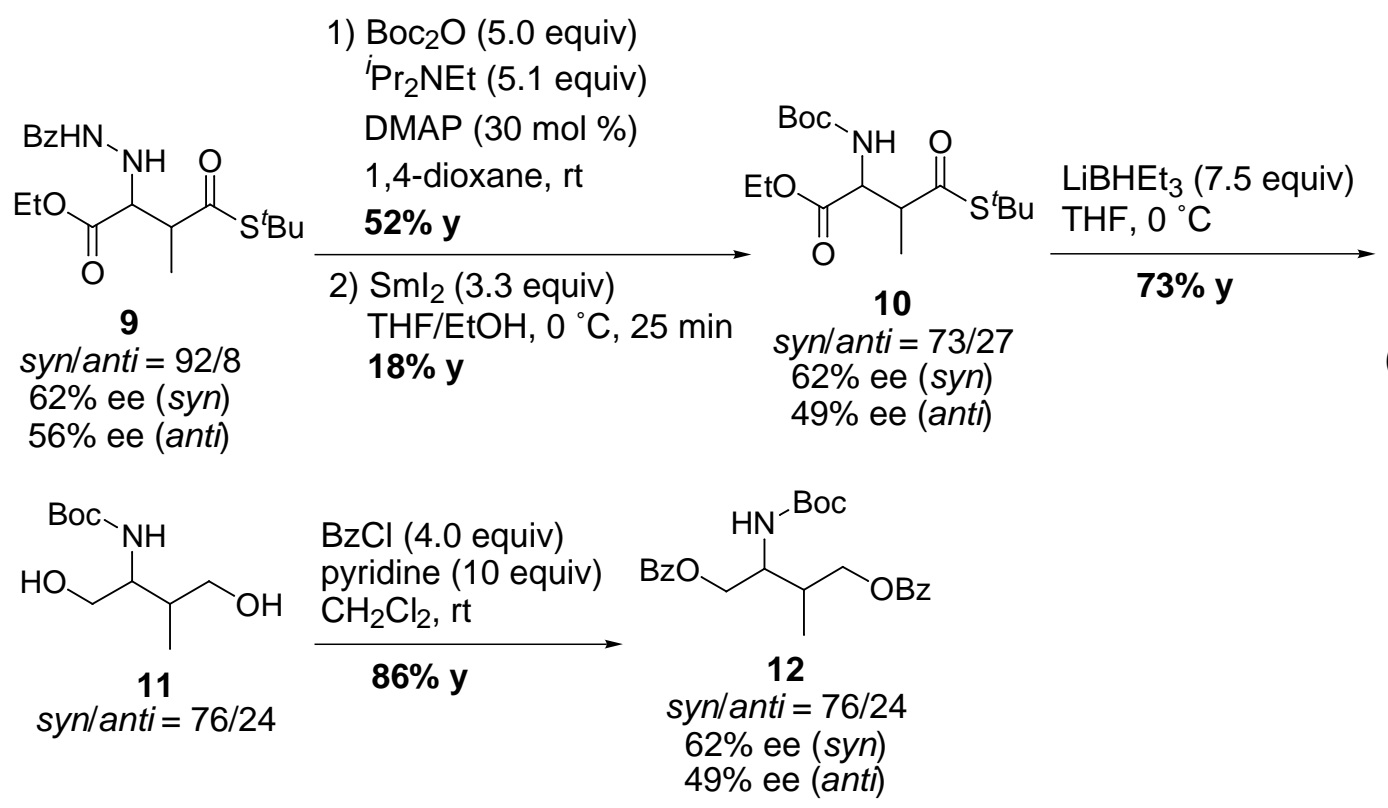

In eq. $2, \mathrm{~N}-\mathrm{N}$ bond cleavage mediated by $\mathrm{SmI}_{2}$ (25 min) gave low yield (18\% yield). However, another set of the reactions (15 min) from 9 (syn/anti = 97/3, 87\% ee (syn), 27\% ee (anti)) gave 10 (syn/anti $=96 / 4,87 \%$ ee (syn), 9\% ee (anti)) in $45 \%$ yield.<smiles>CCCCOC(=O)C(C)C(NNC(=O)c1ccccc1)C(=O)OCC</smiles>

Ethyl 2-(N'-benzoyl- $N$-tert-butoxycarbonylhydrazino)-4-tert-butylthio-3-methyl4-oxobutanoate: To a solution of 9 (syn/anti $=92 / 8,62 \%$ ee $(s y n), 56 \%$ ee (anti)) 
$(0.473 \mathrm{mmol})$ in 1,4 -dioxane $(0.85 \mathrm{~mL})$ were added a solution of $i$ - $\operatorname{Pr}_{2} \mathrm{NEt}(1.73$ $\mathrm{mmol})$ in 1,4-dioxane $(2.3 \mathrm{~mL})$, a solution of di-tert-butyl dicarbonate $(1.69 \mathrm{mmol})$ in 1,4-dioxane $(2.3 \mathrm{~mL})$, and 4-(dimethylamino)pyridine $(0.142 \mathrm{mmol})$ at $\mathrm{rt}$. After stirring for $13 \mathrm{~h}$, a solution of $i$ - $\operatorname{Pr}_{2} \mathrm{NEt}(0.687 \mathrm{mmol})$ and di-tert-butyl dicarbonate $(0.672 \mathrm{mmol})$ in 1,4 -dioxane $(2.3 \mathrm{~mL})$ was added to the mixture. After stirring for 1 $\mathrm{h}$, the reaction was quenched with water. The resultant mixture was extracted with $\mathrm{CH}_{2} \mathrm{Cl}_{2}$ (3 times), and the combined organic layers were dried over anhydrous $\mathrm{Na}_{2} \mathrm{SO}_{4}$. The solvents were evaporated, and the residue was purified by preparative TLC (silica gel, hexane/ethyl acetate (4/1)) to give the desired compound (52\% yield). IR (neat) 3313, 2974, 1721, 1468, 1375, 1281, 1164, 1026, 974, $723 \mathrm{~cm}^{-1}$; ${ }^{1} \mathrm{H}$ NMR $\left(\mathrm{DMSO}-d_{6}, 110{ }^{\circ} \mathrm{C}\right) \operatorname{Syn}$ isomer: $\delta 1.19(\mathrm{t}, 3 \mathrm{H}, J=7.2 \mathrm{~Hz}), 1.32(\mathrm{~d}, 3 \mathrm{H}, J=7.0 \mathrm{~Hz})$, $1.40(\mathrm{~s}, 9 \mathrm{H}), 1.42$ (s, 9H), $3.12(\mathrm{dq}, 1 \mathrm{H}, J=7.0,9.8 \mathrm{~Hz}), 4.01-4.16(\mathrm{~m}, 2 \mathrm{H}), 4.88(\mathrm{brd}$, $1 \mathrm{H}, J=9.8 \mathrm{~Hz}), 7.42-7.51(\mathrm{~m}, 2 \mathrm{H}), 7.53-7.60(\mathrm{~m}, 1 \mathrm{H}), 7.71-7.84(\mathrm{~m}, 2 \mathrm{H}), 9.89(\mathrm{~s}, 1 \mathrm{H})$ ppm; Detectable peaks of anti isomer: $\delta 5.00$ (brd, $1 \mathrm{H}, J=7.0 \mathrm{~Hz}), 9.72(\mathrm{~s}, 1 \mathrm{H}) \mathrm{ppm}$; ${ }^{13} \mathrm{C}$ NMR (DMSO- $\left.d_{6}, 110{ }^{\circ} \mathrm{C}\right): \delta 13.1,15.5,27.3,29.0,47.1,47.5,60.2,64.2,80.6$, 127.0, 127.7, 131.0, 132.5, 153.3, 166.4, 167.4, 201.0 ppm; HRMS (FAB) calcd for $\mathrm{C}_{23} \mathrm{H}_{35} \mathrm{~N}_{2} \mathrm{O}_{6} \mathrm{~S}\left([\mathrm{M}+\mathrm{H}]^{+}\right)$: 467.2216, found: 467.2233 .

10: A $0.1 \mathrm{M}$ solution of $\mathrm{SmI}_{2}$ in THF $(8.2 \mathrm{~mL}, 0.82 \mathrm{mmol})$ was added to a degassed solution of ethyl 2-(N'-benzoyl- $N$-tert-butoxycarbonylhydrazino)-4-tertbutylthio-3-methyl-4-oxobutanoate $(0.247 \mathrm{mmol})$ in $\mathrm{EtOH}(2.62 \mathrm{~mL})$ at $-10{ }^{\circ} \mathrm{C}$. After stirring for $25 \mathrm{~min}$, the reaction was quenched with water. The resultant mixture was extracted with $\mathrm{CH}_{2} \mathrm{Cl}_{2}$ (5 times), and the combined organic layers were dried over anhydrous $\mathrm{Na}_{2} \mathrm{SO}_{4}$. The solvents were evaporated, and the residue was purified by preparative TLC (silica gel, hexane/ethyl acetate (4/1)) to give $\mathbf{1 0}$ (18\% yield).

Diastereomeric ratio of the product was determined from the ratio of integration of the amide proton on ${ }^{1} \mathrm{H}$ NMR analysis (syn/anti $\left.=73 / 27\right)$. The enantiomeric excess of the product was determined by HPLC analysis (62\% ee (syn), 49\% ee (anti)).

${ }^{1} \mathrm{H}$ NMR $\left(\mathrm{CDCl}_{3}\right)$ Syn isomer: $\delta 1.21(\mathrm{~d}, 3 \mathrm{H}, J=6.9 \mathrm{~Hz}), 1.29(\mathrm{t}, 3 \mathrm{H}, J=7.2 \mathrm{~Hz})$, 1.44 (s, 9H), 1.46 (s, 9H), 3.07 (dq, 1H, $J=4.9,6.9 \mathrm{~Hz}), 4.21$ (q, 2H, $J=7.2 \mathrm{~Hz})$, $4.57(\mathrm{dd}, 1 \mathrm{H}, J=4.9,8.5 \mathrm{~Hz}), 5.21(\mathrm{brd}, 1 \mathrm{H}, J=8.5 \mathrm{~Hz}) \mathrm{ppm}$; Detectable peaks of anti isomer: $\delta 5.49$ (brd, 1H, $J=10.0 \mathrm{~Hz}$ ) ppm; HPLC (Daicel Chiralpak AD-H, hexane $/ i-\mathrm{PrOH}=19 / 1$, flow rate $=1.0 \mathrm{~mL} / \mathrm{min}) S y n: t_{\mathrm{R}}=11.1 \mathrm{~min}\left(\right.$ minor), $t_{\mathrm{R}}=14.6$ $\min$ (major). Anti: $t_{\mathrm{R}}=7.3 \min$ (major), $t_{\mathrm{R}}=9.0 \min$ (minor). 
11: This compound was prepared according to the known method from methyl 2-tert-butoxycarbonylamino-4-tert-butylthio-3-methyl-4-oxobutanoate ${ }^{2}$ (73\% yield). Diastereomeric ratio of the product was determined from the ratio of integration of the methyl proton on ${ }^{1} \mathrm{H} \mathrm{NMR}$ analysis $\left(\mathrm{CDCl}_{3}\right)($ syn/anti $=76 / 24)$.

12: To a solution of $11(0.032 \mathrm{mmol})$ in $\mathrm{CH}_{2} \mathrm{Cl}_{2}(0.22 \mathrm{~mL})$ were added a solution of benzoyl chloride $(0.128 \mathrm{mmol})$ in $\mathrm{CH}_{2} \mathrm{Cl}_{2}(0.42 \mathrm{~mL})$ and pyridine $(0.33$ mmol) at rt. After stirring for $18 \mathrm{~h}$, the reaction was quenched with water. The resultant mixture was extracted with $\mathrm{CH}_{2} \mathrm{Cl}_{2}$ (twice), and the combined organic layers were washed with brine, and dried over anhydrous $\mathrm{Na}_{2} \mathrm{SO}_{4}$. The solvent was evaporated, and the residue was purified by preparative TLC (silica gel, hexane/ethyl acetate $(3 / 1))$ to give 12 (86\% yield). Diastereomeric ratio of the product was determined from the ratio of integration of the methyl proton on ${ }^{1} \mathrm{H}$ NMR analysis $\left(\mathrm{CDCl}_{3}\right)($ syn/anti $=76 / 24)$. The enantiomeric excess of the product was determined by HPLC analysis (62\% ee (syn), $49 \%$ ee (anti)).
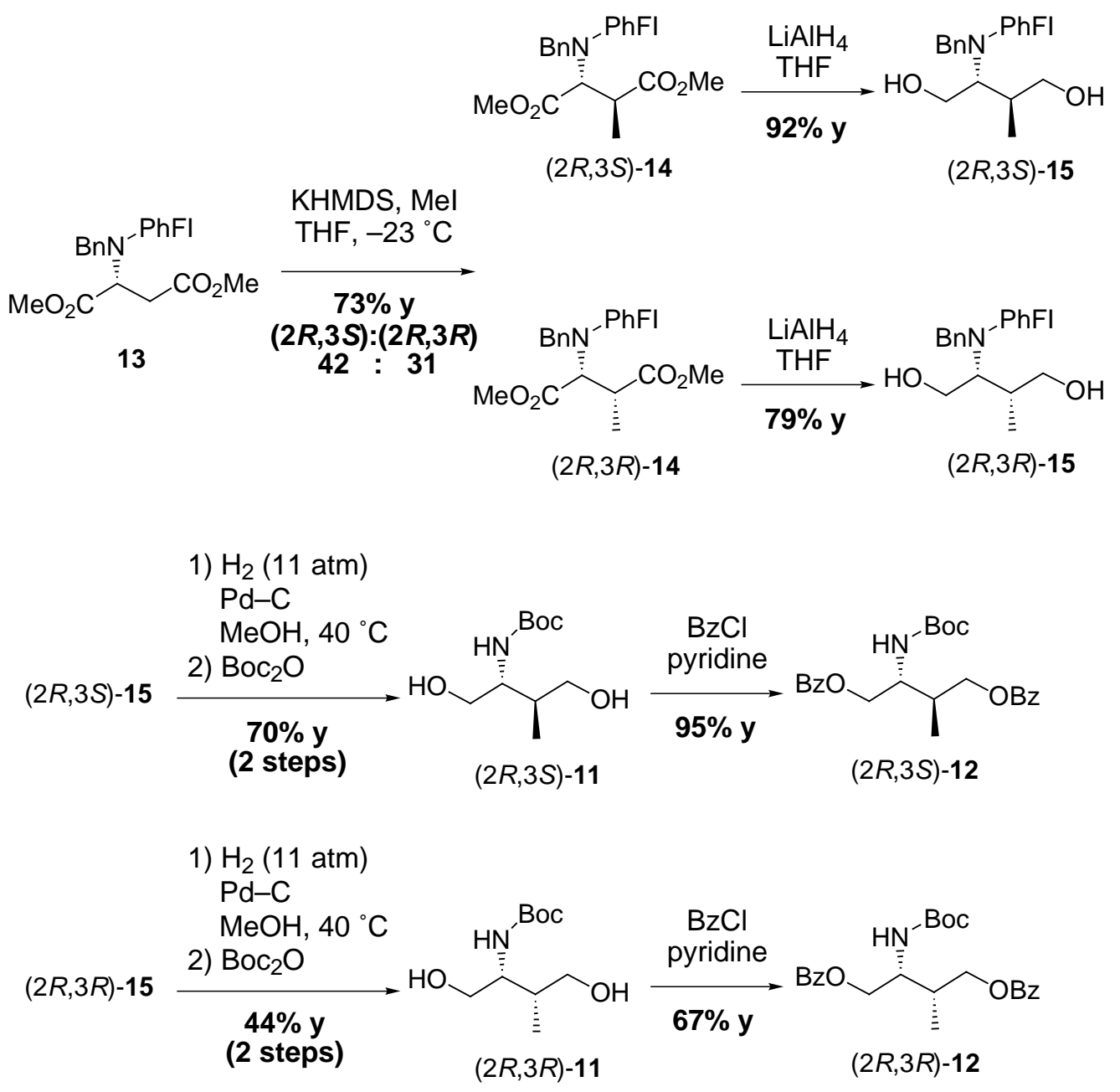
14: $(2 R, 3 S)-\mathbf{1 4}$ and $(2 R, 3 R)-\mathbf{1 4}$ were prepared according to the known method. ${ }^{4}$ $(2 R, 3 S)-14 .{ }^{4}{ }^{1} \mathrm{H}$ NMR $\left(\mathrm{CDCl}_{3}\right): \delta 0.61(\mathrm{~d}, 3 \mathrm{H}, J=7.1 \mathrm{~Hz}), 2.57(\mathrm{dq}, 1 \mathrm{H}, J=7.1$, $11.2 \mathrm{~Hz}), 2.89$ (s, 3H), 3.53 (s, 3H), 3.79 (d, 1H, $J=11.2 \mathrm{~Hz}), 4.35$ (d, 1H, $J=14.3$ $\mathrm{Hz}), 4.69$ (d, 1H, $J=14.3 \mathrm{~Hz}), 7.10-7.36$ (m, 9H), 7.40 (t, 1H, $J=7.4 \mathrm{~Hz}), 7.52-7.77$ $(\mathrm{m}, 7 \mathrm{H}), 7.96-8.02(\mathrm{~m}, 1 \mathrm{H}) \mathrm{ppm} ;{ }^{13} \mathrm{C} \mathrm{NMR}\left(\mathrm{CDCl}_{3}\right): \delta 15.8,40.9,50.6,50.9,51.3$, 62.6, 80.4, 119.3, 119.9, 126.7, 126.7, 127.3, 127.4, 127.5, 127.5, 127.7, 127.9, 128.1, 128.2, 128.5, 129.2, 139.2, 141.5, 142.3, 144.4, 144.7, 147.3, 171.3, 174.3 ppm.

(2R,3R)-1 4. ${ }^{4}{ }^{1} \mathrm{H}$ NMR $\left(\mathrm{CDCl}_{3}\right): \delta 1.14(\mathrm{~d}, 3 \mathrm{H}, J=7.2 \mathrm{~Hz}), 2.27(\mathrm{dq}, 1 \mathrm{H}, J=7.2$, $11.6 \mathrm{~Hz}), 2.95$ (s, 3H), 3.34 (s, 3H), 3.54 (d, 1H, $J=11.6 \mathrm{~Hz}), 4.16$ (d, 1H, $J=13.5$ $\mathrm{Hz}), 4.40(\mathrm{~d}, 1 \mathrm{H}, J=13.5 \mathrm{~Hz}), 7.17-7.38(\mathrm{~m}, 10 \mathrm{H}), 7.43(\mathrm{t}, 1 \mathrm{H}, J=7.4 \mathrm{~Hz}), 7.52-7.90$ $(\mathrm{m}, 7 \mathrm{H}) \mathrm{ppm} ;{ }^{13} \mathrm{C} \mathrm{NMR}\left(\mathrm{CDCl}_{3}\right): \delta 15.3,40.8,51.1,51.4,52.7,62.2,80.0,120.2$, 120.2 , 126.4, 126.8, 126.8, 127.2, 127.4, 127.5, 127.6, 127.9, 128.4, 128.5, 129.7, $139.8,140.1,141.8,144.8,145.5,147.1,171.9,175.5$ ppm.

15: $(2 R, 3 S)-15$ was prepared according to the known method. ${ }^{5}(2 R, 3 R)-\mathbf{1 5}$ was prepared according to a modified procedure of the known method ${ }^{5}$.

$(2 R, 3 S)-15 .{ }^{5}{ }^{1} \mathrm{H}$ NMR $\left(\mathrm{CDCl}_{3}\right): \delta 0.52(\mathrm{~d}, 3 \mathrm{H}, J=7.1 \mathrm{~Hz}), 1.50-1.61(\mathrm{~m}, 1 \mathrm{H}), 1.83$ (brs, 2H), 2.58-2.66 (m, 1H), 2.85 (dd, 1H, $J=5.4,10.5 \mathrm{~Hz}), 3.04$ (dd, 1H, $J=6.6$, $11.0 \mathrm{~Hz}), 3.13(\mathrm{dd}, 1 \mathrm{H}, J=4.6,10.5 \mathrm{~Hz}), 3.25(\mathrm{dd}, 1 \mathrm{H}, J=6.0,11.0 \mathrm{~Hz}), 4.16(\mathrm{~d}, 1 \mathrm{H}$, $J=15.0 \mathrm{~Hz}), 4.28(\mathrm{~d}, 1 \mathrm{H}, J=15.0 \mathrm{~Hz}), 7.16-7.48(\mathrm{~m}, 10 \mathrm{H}), 7.50-7.62(\mathrm{~m}, 2 \mathrm{H}), 7.64-$ $7.82(\mathrm{~m}, 6 \mathrm{H}) \mathrm{ppm} ;{ }^{13} \mathrm{C} \mathrm{NMR}\left(\mathrm{CDCl}_{3}\right): \delta 12.9,36.8,51.2,61.6,61.9,67.8,80.2,120.2$, 120.3 , 126.3, 126.8, 127.0, $127.0127 .5,127.5,127.9$, 128.1, 128.2, 128.4, 128.6, 128.6, 139.9, 140.7, 141.2, 143.7, 147.6, $148.1 \mathrm{ppm}$.

$(2 R, 3 R)-15:$ To a solution of $(2 R, 3 R)-14(0.225 \mathrm{mmol})$ in THF $(3.88 \mathrm{~mL})$ was added $\mathrm{LiAlH}_{4}(0.788 \mathrm{mmol})$ at $0{ }^{\circ} \mathrm{C}$. The reaction mixture was stirred for $5 \mathrm{~min}$ at $0{ }^{\circ} \mathrm{C}$, and stirred for $8 \mathrm{~h}$ at rt. The reaction was quenched with water $(0.20 \mathrm{~mL})$, and stirred for $2 \mathrm{~h}$ at $\mathrm{rt}$. To the mixture was added $15 \%$ aqueous $\mathrm{NaOH}(0.10 \mathrm{~mL})$. After stirring for $44 \mathrm{~h}$ at $\mathrm{rt}$, the resultant mixture was filtered. After washing with THF and ethyl acetate, the filtrate was concentrated, and the residue was purified by preparative TLC ( silica gel, hexane/ethyl acetate (1/1)) to give $(2 R, 3 R)-\mathbf{1 5}$ (79\% yield).

mp: $91-97{ }^{\circ} \mathrm{C} ;[\alpha]_{\mathrm{D}}^{27}+266.2$ (c 0.39, ethyl acetate); IR (KBr): 3375, 2939, 1448, 1032, 739, $700 \mathrm{~cm}^{-1} ;{ }^{1} \mathrm{H}$ NMR $\left(\mathrm{CDCl}_{3}\right): \delta 0.78(\mathrm{~d}, 3 \mathrm{H}, J=6.8 \mathrm{~Hz}), 1.11-1.22(\mathrm{~m}, 1 \mathrm{H})$, 
2.30 (ddd, 1H, $J=3.2,5.6,9.0 \mathrm{~Hz}$ ), 2.45 (brs, 2H), 2.90 (dd, 1H, $J=5.6,11.2 \mathrm{~Hz}$ ), $3.09(\mathrm{dd}, 1 \mathrm{H}, J=3.2,11.2 \mathrm{~Hz}), 3.16(\mathrm{~d}, 2 \mathrm{H}, J=4.4 \mathrm{~Hz}), 4.09$ (d, 1H, $J=13.9 \mathrm{~Hz})$, $4.26(\mathrm{~d}, 1 \mathrm{H}, J=13.9 \mathrm{~Hz}), 7.17-7.45(\mathrm{~m}, 10 \mathrm{H}), 7.52-7.85(\mathrm{~m}, 8 \mathrm{H}) \mathrm{ppm} ;{ }^{13} \mathrm{C} \mathrm{NMR}$ $\left(\mathrm{CDCl}_{3}\right): \delta 17.0,37.8,51.8,63.0,63.4,65.9,79.9,119.8,120.4,126.8,126.9,127.1$, 127.3, 127.4, 127.9, 128.2, 128.3, 128.5, 128.8, 139.8, 140.7, 141.2, 144.3, 147.2, 148.2 ppm; HRMS (FAB) calcd for $\mathrm{C}_{31} \mathrm{H}_{32} \mathrm{NO}_{2}\left([\mathrm{M}+\mathrm{H}]^{+}\right)$: 450.2433, found: 450.2441 .

11: These compounds were prepared according to a modified procedure of the known method. ${ }^{5}$ To a solution of $(2 R, 3 S)-15(0.206 \mathrm{mmol})$ in $\mathrm{MeOH}(3.45 \mathrm{~mL})$ was added 5\% Pd-C (wet) (48.4 mg). The reaction mixture was stirred for $11 \mathrm{~h}$ under $\mathrm{H}_{2}$ (11 atm) at $40^{\circ} \mathrm{C}$. The resultant mixture was filtered, and washed with $\mathrm{MeOH}$ thoroughly. The filtrate was evaporated, and the residue was filtered. After washing with $i$ - $\mathrm{PrNH}_{2}$, the filtrate was evaporated. The residue was dissolved in $i$-PrOH, and the insoluble materials were filtered out. After the filtrate was concentrated, $i$-PrOH (1.82 mL) was added. To the solution was added a solution of di-tert-butyl dicarbonate $(0.417 \mathrm{mmol})$ in $i$ - $\mathrm{PrOH}(1.82 \mathrm{~mL})$. After stirring for $38 \mathrm{~h}$ at $\mathrm{rt}$, the reaction mixture was concentrated, and the residue was purified by column chromatography (silica gel, ethyl acetate) to give $(2 R, 3 S)-\mathbf{1 1}(70 \%$ yield).

$(2 R, 3 S)-11 .{ }^{5}[\alpha]_{D}^{27}+12.6\left(c 0.15, \mathrm{CHCl}_{3}\right) .\left(\mathrm{lit}^{6} ;[\alpha]_{\mathrm{D}}^{20}-10.4\left(c 1, \mathrm{CHCl}_{3}\right)((2 S, 3 R)-\right.$ 11)); IR (neat): 3415, 2947, 1687, 1522, 1379, 1257, 1169, $1063 \mathrm{~cm}^{-1} ;{ }^{1} \mathrm{H}$ NMR $\left(\mathrm{CDCl}_{3}\right): \delta 1.04(\mathrm{~d}, 3 \mathrm{H}, J=7.1 \mathrm{~Hz}), 1.46(\mathrm{~s}, 9 \mathrm{H}), 1.72-1.85(\mathrm{~m}, 1 \mathrm{H}), 2.44$ (brs, 2H), $3.49(\mathrm{dd}, 1 \mathrm{H}, J=4.0,11.6 \mathrm{~Hz}), 3.61$ (dddd, $1 \mathrm{H}, J=4.0,4.6,8.1,8.1 \mathrm{~Hz}), 3.67-3.82$ $(\mathrm{m}, 3 \mathrm{H}), 5.22(\mathrm{brd}, 1 \mathrm{H}, J=4.6 \mathrm{~Hz}) \mathrm{ppm} ;{ }^{1} \mathrm{H} \mathrm{NMR}\left(\mathrm{CDCl}_{3}, 45^{\circ} \mathrm{C}\right): \delta 1.03(\mathrm{~d}, 3 \mathrm{H}, J=$ $7.1 \mathrm{~Hz}), 1.45$ (s, 9H), 1.73-1.85 (m, 1H), 2.21 (brs, 2H), $3.50(\mathrm{dd}, 1 \mathrm{H}, J=4.5,11.6$ $\mathrm{Hz}), 3.57-3.65(\mathrm{~m}, 1 \mathrm{H}), 3.70(\mathrm{dd}, 1 \mathrm{H}, J=3.3,11.6 \mathrm{~Hz}), 3.75(\mathrm{~d}, 2 \mathrm{H}, J=4.2 \mathrm{~Hz}), 5.13$ (brs, $1 \mathrm{H}) \mathrm{ppm} ;{ }^{13} \mathrm{C} \mathrm{NMR}\left(\mathrm{CDCl}_{3}, 45{ }^{\circ} \mathrm{C}\right): \delta 14.8,28.4,37.2,54.3,63.9,64.6,79.9$, 157.1 ppm; HRMS (ESI-TOF) calcd for $\mathrm{C}_{10} \mathrm{H}_{21} \mathrm{NNaO}_{4}\left([\mathrm{M}+\mathrm{Na}]^{+}\right)$: 242.1368, found: 242.1359.

(2R,3R)-11. $[\alpha]_{D}^{26}-8.4\left(c 0.68, \mathrm{CHCl}_{3}\right)$; IR (neat): 3361, 2976, 1687, 1525, 1367 , 1261, 1165, $1032 \mathrm{~cm}^{-1} ;{ }^{1} \mathrm{H} \mathrm{NMR}\left(\mathrm{CDCl}_{3}\right): \delta 0.83(\mathrm{~d}, 3 \mathrm{H}, J=6.8 \mathrm{~Hz}), 1.45(\mathrm{~s}, 9 \mathrm{H})$, 1.91-2.03 (m, 1H), 2.75 (brs, 2H), 3.32-3.43 (m, 1H), 3.44-3.89 (m, 4H), 4.97 (brd, $1 \mathrm{H}, J=8.5 \mathrm{~Hz}) \mathrm{ppm} ;{ }^{1} \mathrm{H} \mathrm{NMR}\left(\mathrm{CDCl}_{3}, 45{ }^{\circ} \mathrm{C}\right): \delta 0.85(\mathrm{~d}, 3 \mathrm{H}, J=6.8 \mathrm{~Hz}), 1.45(\mathrm{~s}$, 9H), 1.89-2.02 (m, 1H), 2.79 (brs, 2H), 3.40 (dd, 1H, $J=8.9,11.2 \mathrm{~Hz}), 3.56$ (dd, 1H, $J=4.1,11.2 \mathrm{~Hz}), 3.65(\mathrm{dd}, 1 \mathrm{H}, J=4.8,11.3 \mathrm{~Hz}), 3.71(\mathrm{dd}, 1 \mathrm{H}, J=5.2,11.3 \mathrm{~Hz})$, 
3.74-3.86 (m, 1H), 4.95 (brs, $1 \mathrm{H}) \mathrm{ppm} ;{ }^{13} \mathrm{C} \mathrm{NMR}\left(\mathrm{CDCl}_{3}, 45{ }^{\circ} \mathrm{C}\right): \delta 11.8,28.4,37.5$, 53.3, 63.3, 64.5, 80.0, 157.0 ppm; HRMS (ESI-TOF) calcd for $\mathrm{C}_{10} \mathrm{H}_{21} \mathrm{NNaO}_{4}$ $\left([\mathrm{M}+\mathrm{Na}]^{+}\right): 242.1368$, found: 242.1372 .

12: These compounds were prepared in a similar manner to that described in eq. 2.

(2R,3S)-12. $[\alpha]_{D}^{27}+28.3\left(c 1.54, \mathrm{CHCl}_{3}\right)$; IR (neat): 3363, 2976, 1722, 1522, 1281 , 1173, 1115, $714 \mathrm{~cm}^{-1}$; ${ }^{1} \mathrm{H}$ NMR $\left(\mathrm{CDCl}_{3}\right): \delta 1.18(\mathrm{~d}, 3 \mathrm{H}, J=6.8 \mathrm{~Hz}), 1.39(\mathrm{~s}, 9 \mathrm{H})$, 2.22-2.34 (m, 1H), 4.07-4.18 (m, 1H), $4.31(\mathrm{dd}, 1 \mathrm{H}, J=5.7,11.3 \mathrm{~Hz}), 4.35-4.56(\mathrm{~m}$, $3 \mathrm{H}), 4.92$ (brd, 1H, $J=9.8 \mathrm{~Hz}), 7.39-7.47(\mathrm{~m}, 4 \mathrm{H}), 7.53-7.60(\mathrm{~m}, 2 \mathrm{H}), 8.01-8.09$ (m, 4H) ppm; ${ }^{1} \mathrm{H}$ NMR (DMSO- $\left.d_{6}, 80{ }^{\circ} \mathrm{C}\right): \delta 1.09(\mathrm{~d}, 3 \mathrm{H}, J=6.8 \mathrm{~Hz}), 1.32(\mathrm{~s}, 9 \mathrm{H}), 2.16-$ $2.29(\mathrm{~m}, 1 \mathrm{H}), 3.91-4.01(\mathrm{~m}, 1 \mathrm{H}), 4.23-4.37$ (m, 3H), 4.45 (dd, $1 \mathrm{H}, J=4.1,11.2 \mathrm{~Hz})$, 6.79 (brs, 1H), 7.44-7.54 (m, 4H), 7.59-7.67 (m, 2H), 7.92-8.04 (m, 4H) ppm; ${ }^{13} \mathrm{C}$ NMR (DMSO- $\left.d_{6}, 80{ }^{\circ} \mathrm{C}\right): \delta 13.8,27.7,33.9,51.3,64.9,66.2,77.5,128.0,128.1$, 128.7, 128.8, 129.6, 129.7, 132.6, 132.7, 155.1, 165.3, 165.3 ppm; HRMS (FAB) calcd for $\mathrm{C}_{24} \mathrm{H}_{30} \mathrm{NO}_{6}\left([\mathrm{M}+\mathrm{H}]^{+}\right)$: 428.2073, found: 428.2049 .

(2R,3R)-12. $[\alpha]^{25}+25.3\left(c 0.555, \mathrm{CHCl}_{3}\right)$; IR (neat): 3377, 2976, 1724, 1520, 1281, 1173, 1115, $714 \mathrm{~cm}^{-1}$; ${ }^{1} \mathrm{H} \mathrm{NMR}\left(\mathrm{CDCl}_{3}\right): \delta 1.13(\mathrm{~d}, 3 \mathrm{H}, J=7.1 \mathrm{~Hz}), 1.40(\mathrm{~s}, 9 \mathrm{H})$, 2.27-2.39 (m, 1H), 4.17-4.48 (m, 5H), $4.76(\mathrm{brd}, 1 \mathrm{H}, J=9.8 \mathrm{~Hz}), 7.39-7.47$ (m, 4H), 7.52-7.59 (m, 2H), 7.99-8.08 (m, 4H) ppm; ${ }^{1} \mathrm{H}$ NMR (DMSO- $\left.d_{6}, 80{ }^{\circ} \mathrm{C}\right): \delta 1.03(\mathrm{~d}$, $3 \mathrm{H}, J=7.1 \mathrm{~Hz}), 1.34$ (s, 9H), 2.18-2.35 (m, 1H), 4.06 (dddd, 1H, $J=5.1,5.1,7.7,9.4$ $\mathrm{Hz}), 4.20(\mathrm{dd}, 1 \mathrm{H}, d=5.7,11.1 \mathrm{~Hz}), 4.27(\mathrm{dd}, 1 \mathrm{H}, J=5.1,11.2 \mathrm{~Hz}), 4.29(\mathrm{dd}, 1 \mathrm{H}, J=$ 3.5, 11.1 Hz), 4.40 (dd, 1H, $J=5.1,11.2 \mathrm{~Hz}), 6.71$ (brs, 1H), 7.44-7.54 (m, 4H), 7.58$7.66(\mathrm{~m}, 2 \mathrm{H}), 7.93-8.00(\mathrm{~m}, 4 \mathrm{H}) \mathrm{ppm} ;{ }^{13} \mathrm{C}$ NMR (DMSO- $\left.d_{6}, 80{ }^{\circ} \mathrm{C}\right): \delta 12.0,27.8$, 33.7, 50.6, 64.9, 66.3, 77.6, 128.1, 128.2, 128.7, 128.8, 129.5, 129.7, 132.7, 132.7, 155.3, 165.3, 165.3 ppm; HRMS (FAB) calcd for $\mathrm{C}_{24} \mathrm{H}_{30} \mathrm{NO}_{6}\left([\mathrm{M}+\mathrm{H}]^{+}\right)$: 428.2073, found: 428.2092 .

HPLC (Chiralcel OD, hexane $/ i-\mathrm{PrOH}=19 / 1$, flow rate $=0.70 \mathrm{~mL} / \mathrm{min})(2 S, 3 R): t_{\mathrm{R}}=$ $14.5 \min .(2 S, 3 S): t_{\mathrm{R}}=16.0 \mathrm{~min} .(2 R, 3 R): t_{\mathrm{R}}=18.0 \mathrm{~min} .(2 R, 3 S): t_{\mathrm{R}}=20.1 \mathrm{~min}$.

The relative configuration of the product of the reaction with propiophenonederived silyl enol ether was assumed to be syn. ${ }^{1}$ The absolute configuration was assumed to be (2R)-form by analogy to Mannich-adducts from acetophenone-derived silyl enol ether, $\mathbf{4 E}$ and $\mathbf{4 Z}$. 
The stereochemistry of the product of the reaction with butyrophenone-derived silyl enol ether was assumed to be $(2 R, 3 R)$ by analogy to that of propiophenonederived silyl enol ether.

The absolute configuration of 5 was assumed to be $(2 R)$-form by analogy to the products of the reactions with acetophenone-derived silyl enol ether, $\mathbf{4 E}$, and $\mathbf{4 Z}$.

\section{References}

1) Kobayashi, S.; Hamada, T.; Manabe, K. J. Am. Chem. Soc. 2002, 124, 5640.

2) Nakamura, Y.; Matsubara, R.; Kiyohara, H.; Kobayashi, S. Org. Lett. 2003, 5, 2481.

3) Wolf, J. P.; Rapoport, H. J. Org. Chem. 1989, 54, 3164.

4) Humphrey, J. M.; Bridges, R. J.; Hart, J. A.; Chamberlin, A. R. J. Org. Chem. 1994, 59, 2467.

5) Yoshida, T.; Takeshita, M.; Orita, H.; Kado, N.; Yasuda, S.; Kato, H.; Itoh, Y. Chem. Pharm. Bull. 1996, 44, 1128. 
X-Ray Structure of $\mathrm{ZnCl}_{2}-1 \mathrm{~b}-\mathrm{CH}_{2} \mathrm{Cl}_{2}$

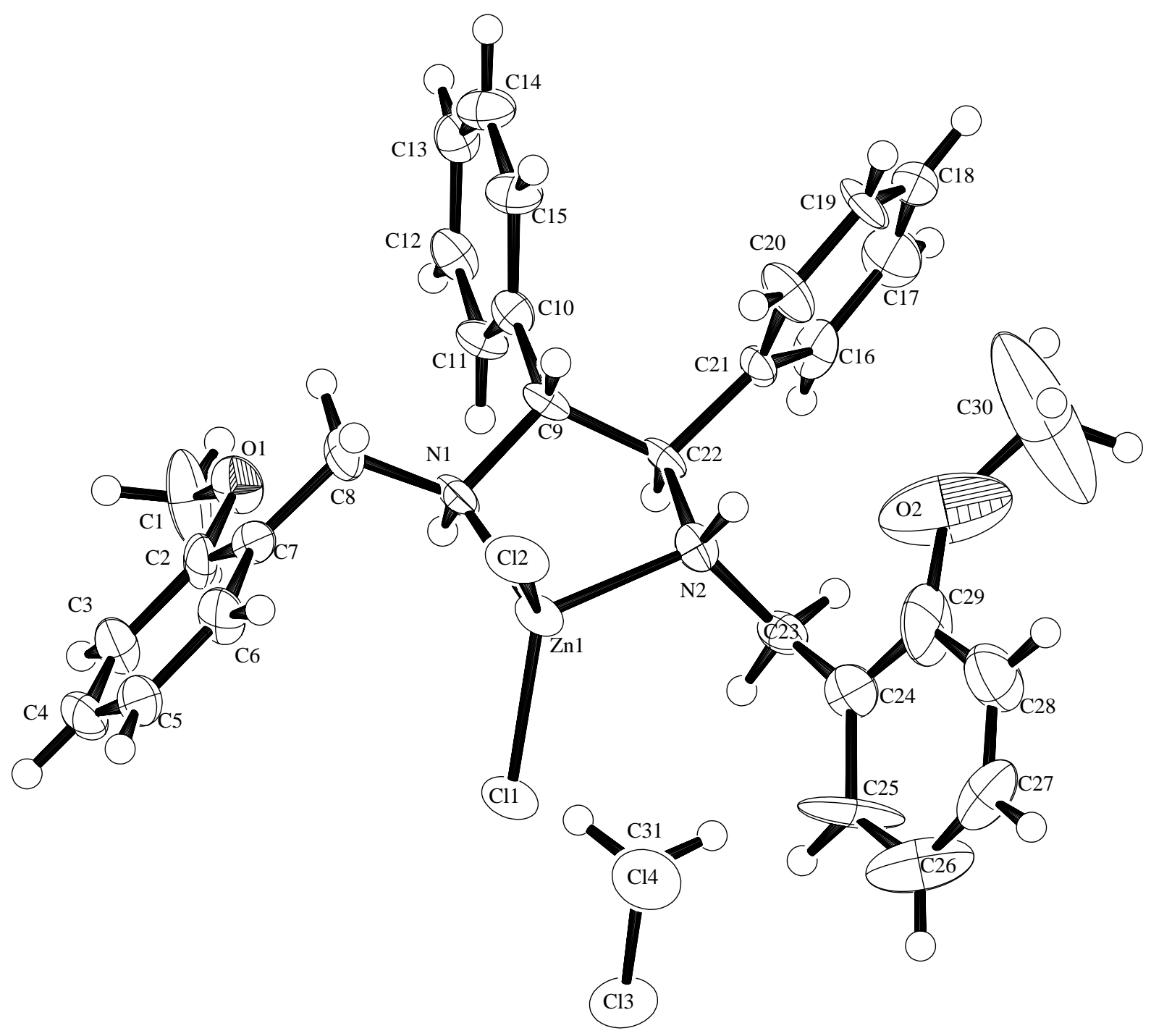


X-Ray Structure of 8

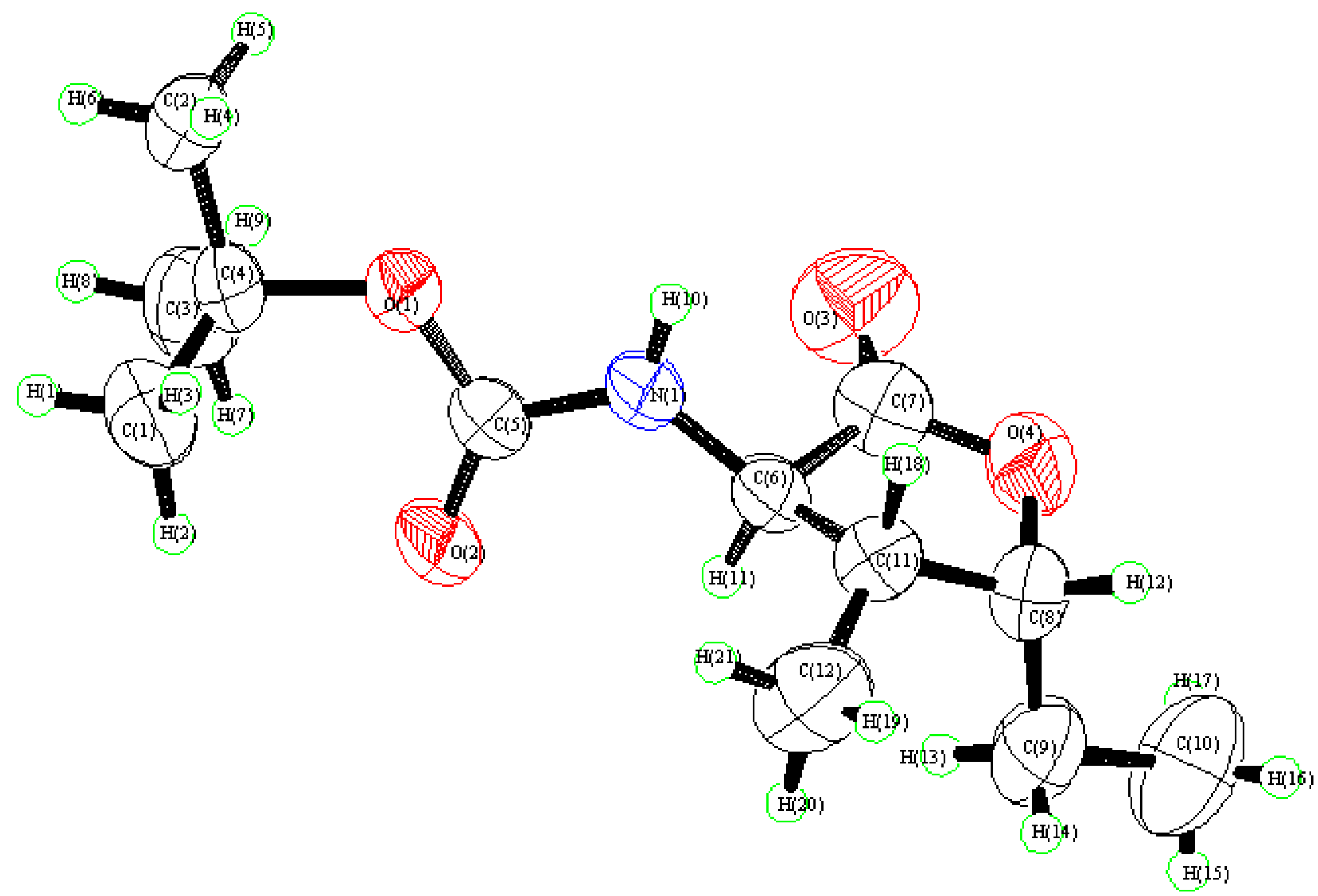

